\title{
Removal of the cortical projections alters expression of NOS in the different cell types of the superficial layers of the superior colliculus in rats
}

\author{
FRANK TENÓRIO ${ }^{1}$, ARTHUR GIRALDI-GUIMARÃES ${ }^{2}$ and ROSALIA MENDEZ-OTERO ${ }^{2}$ \\ ${ }^{1}$ Departamento de Farmacologia e Psicobiologia, Instituto de Biologia Roberto Alcântara Gomes, UERJ \\ 20551-030 Rio de Janeiro, Brazil \\ ${ }^{2}$ Instituto de Biofísica Carlos Chagas Filho, UFRJ, 21941-590 Rio de Janeiro, Brazil
}

Manuscript received on September 13, 2002; accepted for publication on September 20, 2002;

contributed by Rosalia MendeZ-OTERo*

\begin{abstract}
Nitric oxide has several biological roles and nitric oxide synthase (NOS) is expressed in the nervous system, and co-localizes with NADPH-diaphorase. The superficial layers of the superior colliculus (SC), which receive retinal and cortical inputs, present NADPH-d staining in a sub-population of neurons that include all cell types. We have previously shown, by NADPH-diaphorase, that eye enucleation alters the intracellular distribution of NOS. Here, we studied the effect of cortical ablation on NOS expression by neurons in collicular superficial layers. Our results show that cortical ablation alters the proportion of different NOS-positive cell types, but not the intracellular distribution of the enzyme.
\end{abstract}

Key words: superior colliculus, nitric oxide, visual cortex, NADPH-diaphorase.

\section{INTRODUCTION}

Nitric oxide (NO) is a gas that plays several roles in the central nervous system. Nitric oxide synthase (NOS) is highly expressed in the nervous system and NADPH-diaphorase staining is highly correlated with NOS activity (Bredt et al. 1991, Dawson et al. 1991, Hope et al. 1991, Matsumoto et al. 1993). Despite of being a constitutive enzyme, neuronal NOS activity and its sub cellular distribution appears to be actively regulated at multiple levels (Vincent 1995).

Results form different laboratories suggest that retinal projections and/or its neural activity might have a role in the expression of this enzyme in the

\footnotetext{
*Member of Academia Brasileira de Ciências

Correspondence to: Frank Tenório

E-mail: ftenorio@uerj.br
}

visual system. Light deprivation enhances NOS activity in the lateral geniculate nucleus (LGN) of mice and rabbits (Ientile et al. 1996) and enhances NADPH-d staining in the LGN of cats (Gunluk et al. 1994). Monocular enucleation also alters NOS distribution in the monkey visual cortex (Aoki et al. 1993).

In previous studies we have shown in rats that the removal of the retinocollicular projections by enucleation lead to an alteration of intracellular distribution of NADPH-d staining in NOS positive neurons at the superior colliculus superficial layers (Tenório et al. 1998). The superficial layers of the SC also receive an input from cortical pyramidal cells of ipsilateral visual cortex (Bolz et al. 1991). To investigate whether cortical projections have some influence in NOS expression in the superior collicu- 
lus superficial layers, we studied the pattern of NADPH-d staining in neurons from these layers in animals in which the normal pattern of corticocollicular projections was disturbed by removal of the visual cortex.

\section{MATERIALS AND METHODS}

Lister rats from our breeding colony were used. All chemicals were purchased from Sigma Chemical Co. (St. Louis, MO). Newborn animals (P0) were anaesthetized by hypothermia to be submitted to visual cortex removal surgery $(\mathrm{n}=5)$. An incision was made at the top of the head. The skull was opened and the region corresponding to the left occipital cortex was aspirated with a pipette tip attached to a pump. The left SC was the experimental one and the right $\mathrm{SC}$ of the same animal was used as the control. The animals were sutured and returned to their mother after recovering from the surgery. In addition, control animals ( $n=9)$ were used for comparison. At ages between P30 and P60, animals were anaesthetized with sodium pentobarbital $(50 \mathrm{mg} / \mathrm{kg})$ and intracardially perfused with $0.9 \%$ saline solution followed by $4 \%$ paraformaldehyde (PF) in $100 \mathrm{mM}$ phosphate buffer ( $\mathrm{pH}$ 7.4). After dissection, the brains were immersed in $100 \mathrm{mM}$ phosphate buffer containing $20 \%$ sucrose, overnight at $4^{\circ} \mathrm{C}$ and then sectioned at $60 \mu \mathrm{m}$ on a cryostat at $-20^{\circ} \mathrm{C}$ in the coronal or parasagital planes. Sections containing the SC were collected in $50 \mathrm{mM}$ Tris buffer $(\mathrm{pH}$ 7.4), washed twice in this buffer and submitted to NADPH-d histochemistry technique. After $1 \mathrm{~h}$ at $37^{\circ} \mathrm{C}$ under constant shaking, reaction was interrupted, sections were washed twice in Tris buffer and mounted in gelatinized slides. The slides with sections were dehydrated and coversliped. Photomicrographs were made using a Zeiss Axioplan microscope. Cell counts were performed under a $40 \mathrm{X}$ objective. Four fields in sections of 4 animals of each group were used. Piriform and wide field vertical cells were included in the same group (ganglion cells type I and II). The differences between the control group and ablated animals were analyzed using a $\chi^{2}$-test for $\mathrm{k}$ independent samples; critical values of $\mathrm{p}<0.001$ were used for analyses.

\section{RESULTS AND DISCUSSION}

Previously we have shown that eye enucleation do not interfere with the temporal sequence of NOS expression in the rat SC superficial layers, although it alters the intracellular distribution of this enzyme by these cells (Tenório et al. 1998). After removal of the retinal projections the SC superficial layers still receive projections from the ipsilateral visual cortex. The removal of these collicular afferents could origin different changes, from those seem in enucleated animals, in the pattern of NOS expression by neurons of the SC superficial layers.

Our results showed no significant difference in the general pattern of NADPH-d staining between the deafferented and the afferented SC (Fig.1). The staining pattern in these animals was also very similar to the pattern described in control animals SC (non operated) (data not shown). In normal animals we have demonstrated that (Tenório et al. 1996), a sub-population of all the different cell types described with the Golgi staining in the rat SC (Langer and Lund 1974) expressed NOS (Tenório et al. 1996). The same cell types were also stained in both deafferented and afferented SC of the ablated animals. However, cell counts in normal and ablated animals revealed that the proportion of NADPH-d stained cells was altered in relation to the different cell types (Table I). Narrow field vertical cells showed a marked decrease $(54.6 \%)$ in their proportion in relation to other cells types when comparing control and ablated animals. On the other hand, stellate cells are the ones that shown the more pronounced increase in proportion to other cell types tripling their number. Type I and II ganglion cells and horizontal cells (deep and surface) double their number in ablated animals in comparison to control animals (232.18\%; 171.43\%; 200.00\% respectively). Marginal, type III ganglion cells and nonclassified cells showed no significant difference in their proportion in relation to the control group. 

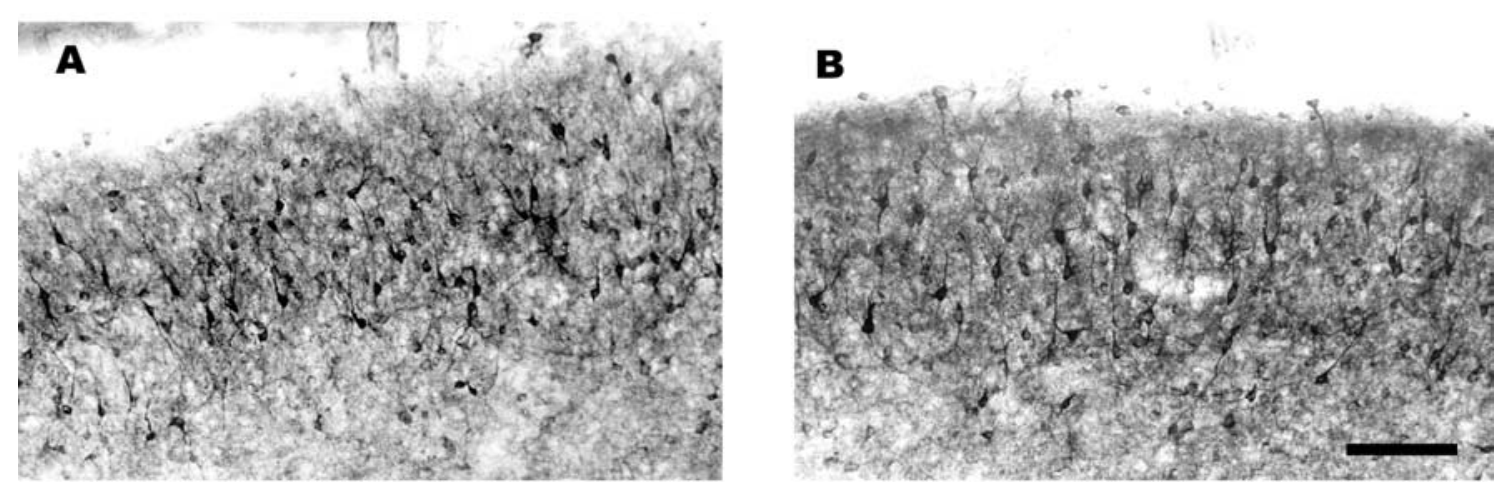

Fig. 1 - Photomicrograph of the superior colliculus of an animal P31 whose cortex was removed at P0. (A) SC contralateral to the removed cortex. (B) SC ipsilateral to the removed cortex. No significant difference was observed in the NADPH-d pattern. NOS was present in the cell bodies and in dendrites of the cells. The neuropil is also stained in both SCs. Scale bar: $100 \mu \mathrm{m}$.

TABLE I

Cellular types in control and experimental animals.

\begin{tabular}{l|c|c|c|c}
\hline Cell type & Control (\%) & $\mathrm{n}$ & Ablated (\%) & $\mathrm{n}$ \\
\hline Marginal cell & 22,89 & 195 & 22,00 & 190 \\
Narrow field vertical cell* & 42,96 & 366 & 23,25 & 200 \\
Type I and II ganglion cell* & 10,21 & 87 & 23,45 & 202 \\
Type III ganglion cell & 3,64 & 31 & 3,45 & 30 \\
Stellate cell* & 3,05 & 26 & 9,05 & 78 \\
Surface horizontal cell* & 1,64 & 14 & 2,70 & 24 \\
Deep horizontal cell* & 2,58 & 22 & 5,00 & 44 \\
Non-classified cells & 13,03 & 111 & 11,10 & 96 \\
\hline Total & 100,00 & 852 & 100,00 & 860 \\
\hline
\end{tabular}

$\mathrm{P}<0,001$ ( $\chi^{2}$ to $\mathrm{k}$ independent samples) differences between the control group and ablated animals. *correspond to statistical differences.

The difference in the results between the ablation of retinal afferents and cortical inputs shows that these projections might have different influences on the expression of NOS by SC cells and it is possible to suggest that this difference might be correlated with different functional roles of these afferents. In fact, it has been shown that the ablation of visual cortex facilitated induction of LTP in the SC superficial layers, indicating that the corticocollicular projection could have a modulatory function, blocking the enhancing of the synaptic transmission proba- bly by activation of GABAergic neurons (Hirai and Okada 1993). In various mammalian species, the SC superficial layers contain the highest amount of GABA, and the main source of this neurotransmitter in these layers is the large number of GABAergic interneurons (Mize et al. 1982, Okada 1974). We have previously shown that $20 \%$ of all NOS-positive cells in the rat SC superficial layers also expressed GABA (Soares-Mota et al. 2001). It is difficult at this time to establish any correlation between these data, and work in our lab is in progress to deter- 
mine which collicular cell types are double-stained by NOS and GABA, and what are the effects of the ablation of the visual cortical and retinal afferents in this co-expression. However, results from other laboratories allow us to make some inferences. In cats, the GABAergic neurons have the cortical projections as a very important synaptic source (Mize 1988). These cells were described as horizontal I, granule I and granule II and, by the morphological similarities, they probably correspond to the superficial horizontal and the ganglion cells, respectively, described in rats and found in our work. Our results showed that cortical ablation induces an increase in the proportion of the NADPH-d stained cells of these groups, in relation to control animals. Then it is possible to suggest that the absence of cortical projections, which is an important source of synaptic input to these cells, directly induces an increase in the NOS expression by them. However, there are a few points against this conclusion. First, the afferent inputs to the deep horizontal cells, the proportion of which also increases, are unknown. Second, although there are a large number of reports involving the study of the sensory processing in the SC, the complete synaptic circuitry underlying SC function remains not completely understood. So, it is also possible that the effects we described after removal of the cortical projection are due to indirect effects of the absence of these projections onto SC cells.

\section{RESUMO}

O óxido nítrico apresenta diversos papéis biológicos e a óxido nítrico sintase (ONS) é expressa no sistema nervoso, co-localizando-se com a NADPH-diaforase. As camadas superficiais do colículo superior (CS), as quais recebem aferências retinianas e corticais, possuem marcação para NADPH-diaforase numa sub-população de neurônios que inclui todos os tipos celulares. Previamente demostramos, por NADPH-diaforase, que a enucleação ocular altera a distribuição intracelular da ONS. Neste trabalho estudamos o efeito da ablação cortical na expressão da ONS por neurônios das camadas superficiais coliculares. Nossos resultados demonstraram que a ablação cortical altera as proporções dos diferentes tipos celulares ONS positivos mas não a distribuição intracelular da ONS.

Palavras-chave: colículo superior, óxido nítrico, córtex visual, NADPH-diaforase.

\section{REFERENCES}

Aoki C, Fenstemaker S, Lubin M and Go C-G. 1993. Nitric oxide synthase in the visual cortex of monocular monkeys as revealed by light and electron microscopic immunocytochemistry. Brain Res 620: 97-113.

Bolz J, Hübener M, Kehrer I ANd NovaK N. 1991. Structural organization and development of identified projection neurons in primary visual cortex. In BAGNOLI P AND Hodos W (Eds), The Changing Visual System, New York: Plenum, pp. 233-246.

Bredt DS, Glatt CE, Hwang PM, Fotuhi M, Dawson TM AND SNYDER SH. 1991. Nitric oxide synthase protein and mRNA are discretely localized in neuronal populations of the mammalian CNS together with NADPH diaphorase. Neuron 7: 615-624.

Dawson VL, DAwson TM, London ED, BREDT DS AND SNYDER SH. 1991. Nitric oxide mediates glutamate neurotoxicity in primary cortical cultures. Proc Natl Acad Sci USA 88: 6368-6371.

Gunluk AE, Bickford ME And Sherman SM. 1994. Rearing with monocular lid suture induces abnormal NADPH-diaphorase staining in the lateral geniculate nucleus of cats. J Comp Neurol 350: 215-228.

Hirai H AND OKada Y. 1993. Ipsilateral corticotectal pathway inhibits the formation of long-term potentiation (LTP) in the rat superior colliculus through GABAergic mechanism. Brain Res 629: 23-30.

Hope BT, Michael GJ, Knigge KM and Vincent SR. 1991. Neuronal NADPH diaphorase is a nitric oxide synthase. Proc Natl Acad Sci USA 88: 2811-2814.

Ientile R, Picciurro V, Pedale S, Nucci C, Malecka B, Nistico G and Macaione S. 1996. Nitric oxide enhances amino acid release from immature chick embryo retina. Neurosci Lett 219: 79-82.

LANGER TP AND Lund RD. 1974. The upper layers of the superior colliculus: A Golgi study. J Comp Neurol 158: 405-435.

Matsumoto T, Nakane M, Pollock JS, Kuk JE AND 
FORSTERMANN Y. 1993. A correlation between soluble brain nitric oxide synthase and NADPHdiaphorase activity is only seen after exposure of the tissue to fixative. Neurosci Lett 155: 61-64.

Mize RR. 1988. Immunocytochemical localization of gamma-aminobutyric acid (GABA) in the cat superior colliculus. J Comp Neurol 276: 169-187.

Mize RR, Spencer RF and Sterling P. 1982. Two types of GABA-accumulation neurons in the superficial gray layer of the cat superior colliculus. J Comp Neurol 206: 180-192.

OKADA Y. 1974. Distribution of $\gamma$-aminobutyric acid (GABA) in the layers of superior colliculus of the rabbit. Brain Res 75: 362-365.
Soares-Mota M, Henze I and Mendez-Otero R. 2001. Nitric oxide synthase-positive neurons in the rat superior colliculus: colocalization of NOS with NMDAR1 glutamate receptor, GABA and parvalbumin. J Neurosci Res 64: 501-507.

Tenório F, Giraldi-Guimarães A and MendezOTERo R. 1996. Morphology of NADPH-diaphorase-positive cells in the retinoceptive layers of the developing rat superior colliculus. Int J Dev Neurosci 14: $1-10$.

Tenório F, Giraldi-Guimarães A, Santos Hr, Cintra WM AND MEndeZ-OTERo R. 1998. Eye enucleation alters intracellular distribution of NO synthase in the superior colliculus. Neuro Report 9: 145-148.

VINCENT S. 1995. Nitric oxide in the nervous system. Academic Press, 1995. 